\title{
Microbiological evaluation of antibacterial potentiality of some edible plant extracts against multidrug resistant (MDR) human pathogens
}

\author{
*Mohamed Helal El-Sayed ${ }^{1,2}$, Bahgat Mohamed Refaat ${ }^{2}$ and Mohamed Hamed Sharaf ${ }^{2}$ \\ ${ }^{1}$ Biology Department, Faculty of Science and Arts, Northern Border University (Rafhaa), Kingdom of Saudi Arabia \\ ${ }^{2}$ Botany and Microbiology Department, Faculty of Science (Boys), Al-Azhar University, Cairo, Egypt
}

\begin{abstract}
Antimicrobial resistance is a subject of great concern in public health and also in the designing of strategies for current therapeutic protocols all over the world. Plants used for traditional medicine contain a wide range of substances which can be used to treat various infectious diseases. Hence, antibacterial activities of aqueous extracts of 10 plant species were studied against 25 multidrug resistant (MDR) clinical isolates using the agar well diffusion method. The most resistant organisms were Acinetobacter baumanii (A. baumanii) (resistant to 16 different antibiotics), Enterococcus faecium (E. faecium) (resistant to 15 different antibiotics), Pseudomonas aeruginosa ( $P$. aeruginosa) (resistant to 15 antibiotics), Gemella morbillorum (G. morbillorum) (resistant to 14 different antibiotics), Enterobacter cloacae (E. cloacae) (resistant to 13 different antibiotics) respectively. Among the tested plant extracts, only extracts of Allium cepa, Allium sativum, Foeniculum vulgare, Matricaria chmomilla, Salvia offcinalis and Thymus Vulgaris showed strong antibacterial activity against MDR isolates with inhibition zones ranging from 8.33 to $26 \mathrm{~mm}$. The minimum inhibitory concentration (MIC) and minimum bactericidal concentration (MBC) of the most active plant extracts; Allium cepa and Foeniculum vulgare were ranged from 0.062 to $0.25 \mathrm{mg} / \mathrm{ml}$ and 0.031 to $0.125 \mathrm{mg} / \mathrm{ml}$, respectively. Foeniculum vulgare extract was bactericidal for all bacteria while Allium cepa extract was bacteriostatic. Hence, the discovered compounds from these plants can use as templates for the development of new antibacterial agents.
\end{abstract}

Key Words: Antibacterial activity, clinical isolates, drug-resistant, medicinal plants.

\section{INTRODUCTION}

In the last many years the commercial antimicrobial drugs were used to control the microbial pathogenecity and other infectious diseases. Excess use of antibiotics results in multiple drug resistance (MDR) in many bacterial pathogens. Successful treatment of infectious diseases and control of microbial pathogenicity results in increasing the drug resistance (Fu et al., 2007). Similarly, preservatives like sulfites, nitrates, nitrites and antibiotics, are harmful for human health and have many side effects, including headache, nausea, weakness, mental retardation, seizures, cancer and anorexia (Rangan and Barceloux, 2009).

Although production of new antibacterial compounds by the pharmaceutical companies had been increased in the last years, the resistance of the microbial pathogens to these drugs was also increased (Adwan and Mhanna, 2008). The global emergence of multi-drug resistant (MDR) bacteria significantly causing treatment failure due to increasingly limiting the effectiveness of current drugs (Hancock, 2005). Bacterial resistance to chemically unrelated antimicrobial agents is a public health concern (Sharma et al., 2005) and may be caused by over-expression of MDR efflux pumps (Li and Nikaido, 2004).

Emergence of antimicrobial resistance is due to losing the activity of numerous classes of antimicrobial agents, often as a result of the selective pressure of antimicrobial usage. Among the important emerging resistance problems are penicillin resistance in streptococci, vancomycin resistance in enterococci (and eventually
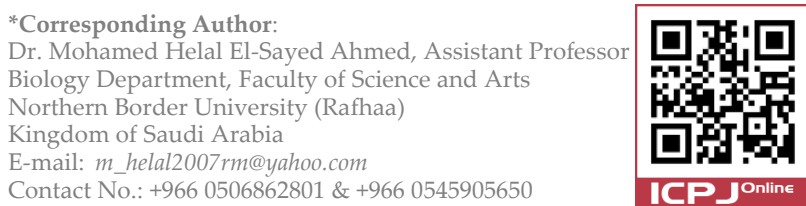

staphylococci), oxacillin resistance in staphylococci, resistance to extended-spectrum Enterobacteriaceae, and carbapenem resistance in P. aeruginosa (Pfaller et al., 1998), and carbapenem resistance in $P$. aeruginosa (Pfaller et al. 1998), aminopenicillins, ureidopenicillins, first and second-generation cephalosporins, cephamycins, most aminoglycosides, chloramphenicol, and tetracyclines resistance in A. baumannii (Murray and Moellering, 1979).

Because the resistance to antibiotics had been increased, the need to discover new and innovative antimicrobial agents has also increased. For thousands of years, using of natural products for treatment of infectious diseases and controlling of microbial pathogenicity all over the world is the major alternative way to predate the introduction of antibiotics and other modern drugs. It is estimated that local communities have used about $10 \%$ of all flowering plants on Earth to treat various infections, although only $1 \%$ have gained recognition by modern scientists (Kafaru, 1994). The popular use of the plants as remedies for treatment of many infectious diseases, searches for plants containing antimicrobial substances are frequent (Betoni et al., 2006).

Plants contain a variety of important secondary metabolites as tannins, alkaloids and flavonoids, which possess in vitro antimicrobial properties (Lewis and Ausubel, 2006). Phytotherapy manuals recorded a various medicinal plants used for infectious diseases treatment because of their availability, fewer side effects and reduced toxicity (Lee et al., 2007).

Several studies discussed the antimicrobial activity of different plant extracts (Bonjar, 2004; Islam et al., 2008; de Boer et al., 2005). Some plants exhibited a good treatment for the urinary tract infections, gastrointestinal disorders, respiratory diseases and cutaneous infections (Brantner and Grein, 1994; Somchit et al., 2003). Using plants for medicinal purposes is an important part of the culture and the tradition in Egypt. Therefore, this in vitro 
Table 1: List of the studied plants.

\begin{tabular}{|c|c|c|c|c|c|}
\hline \multirow{2}{*}{ No } & \multicolumn{3}{|c|}{ Studied plants } & \multirow{2}{*}{ Family } & \multirow{2}{*}{ Plant part } \\
\hline & Local name & English name & Botanical name & & \\
\hline 1 & Bassal & Onions & Allium cepa & Amaryllidaceae & Derna \\
\hline 2 & Thoum & Garlic & Allium satioum & Amaryllidaceae & Lobes mature \\
\hline 3 & Shamar & Fennel & Foeniculum vulgare & Apiaceae & seeds \\
\hline 4 & Moghat & Calotropis & Glossostemon bruguieri & Steculiaceae & root \\
\hline 5 & Bapong & Chamomile & Matricaria chmomilla & Asteraceae & Blooming flowers \\
\hline 6 & Habbat al-barakah & Black Cumin & Nigella sativa & Ranunculaceae & seeds \\
\hline 7 & Ikleel Al Jabal & Rosemary & Rosmarinus officinailis & Lamiaceae & Leaves, stems \\
\hline 8 & Maramia & Sage & Salvia offcinalis & Lamiaceae & Leaves, flowering heads \\
\hline 9 & Zatar & Thyme & Thymus Vulgaris & Lamiaceae & Flowering branches \\
\hline 10 & Zanjabil & Ginger & Zingiber officinale & Zingiberaceae & Alrizumat \\
\hline
\end{tabular}

study was aimed at screening selected plants for their antibacterial activity and evaluating their potential use in treating infections caused by multi-drug resistant clinical bacteria.

\section{MATERIALS AND METHODS}

Plant materials and preparation of the aqueous extracts Ten edible plants used in this work were purchased from the local Egyptian herbal. The plant parts used were) Derna, Lobes mature, seeds, root, Blooming flowers, Leaves, stems, flowering heads, Flowering branches, Alrizumat), data are recorded in table 1 . The above plant parts were cut, washed with distilled water, dried and then powdered finely using electric blender. 10 grams of ground, air-dried plant material was soaked in $100 \mathrm{ml}$ of distilled water in conical flasks, and then incubated at room temperature for 72 hours with shaking at $120 \mathrm{rpm}$. Centrifugation of the crude extracts was carried out at $3000 \mathrm{rpm}$ for 10 minutes at $25^{\circ} \mathrm{C}$ then evaporated at $80^{\circ} \mathrm{C}$ in a rotary evaporator. The dried extracted samples were dissolved in distilled water separately to the concentration of $100 \mathrm{mg} / \mathrm{ml}$ and further centrifuged at 10,000 rpm to remove the undissolved residues. The extract solutions were stored at $4^{\circ} \mathrm{C}$ for further experiments.

\section{Bacterial strains}

The bacterial strains used in this study included the following clinical isolates; A. baumannii (Tetracycline-, vancomycin-, piperacillin-, clindamycin-, trimethoprime/sulfomethoxazole-, oxacillin-, azactam-, ciprofloxacin-, flucloxacillin-, ampicillin-, gentamycin-, bacitracin-, chloramphenicol-, erythromycin-, tobramycinand rifampicin-resistant, and amikacin-sensitive), $E$. faecium (Tetracycline-, vancomycin-, piperacillin-, clindamycin-, trimethoprime/sulfomethoxazole-, oxacillin-, azactam-, ciprofloxacin-, flucloxacillin-, ampicillin-, gentamycin-, bacitracin-, chloramphenicol-, erythromycin and rifampicin-resistant, tobramycin-intermediate,and-, Amikacin-resistant), P. aeruginosa (Tetracycline-, vancomycin-, piperacillin-, clindamycin-, trimethoprime/ sulfomethoxazole-, oxacillin-, ciprofloxacin-, flucloxacillin-, ampicillin-, gentamycin-, bacitracin-, chloramphenicol-, erythromycin-, tobramycin- and rifampicinresistant-and azactam- intermediate, and Amikacinsensitive), G. morbillorum (Tetracycline-, vancomycin-, piperacillin-, clindamycin-, trimethoprime/ sulfomethoxazole-, oxacillin-, azactam-, flucloxacillin-, ampicillin-, gentamycin-, chloramphenicol-, erythromycin-, rifampicin- and ciprofloxacin-resistant, and tobramycin- and bacitracin-intermediate, and amikacin-sensitive), E. cloacae (Tetracycline-, vancomycin-, piperacillin-, clindamycin-, oxacillin-, flucloxacillin-, ampicillin-, gentamycin-, bacitracin-, chloramphenicol-, erythromycin-, rifampicinand tobramycin-resistant, and Azactam- and trimethoprime/Sulfomethoxazole-interme-diate, and amikacinand ciprofloxacin-sensitive). Also, Gram-positive S. aureus ATCC 29213 and Gram-negative E. coli ATCC 25922 were used as reference strains for comparison of MIC and inhibition zones.

\section{Culture preparation}

The bacterial strains were inoculated in $1 \mathrm{ml}$ MuellerHinton Broth (MHB) and grown overnight at $37^{\circ} \mathrm{C}$ separately before performing antimicrobial assay. Each bacterial strain was refreshed by inoculation of $50 \mu \mathrm{l}$ of overnight culture into $5 \mathrm{ml}$ of $\mathrm{MHB}$ (pH 7.2) under aseptic conditions then shaken for 16 hours in a water bath at $37^{\circ} \mathrm{C}$. The bacterial cells were harvested by centrifugation at $4^{\circ} \mathrm{C}$ for 15 minutes with $3000 \mathrm{rpm}$ then washed twice with phosphate buffer saline ( $\mathrm{pH} 7.4)$ and resuspended in MHB. The inoculum concentration was adjusted to $10^{7}$ $\mathrm{CFU} / \mathrm{ml}$

Antimicrobial assay using the disc diffusion method The disc diffusion method for antimicrobial susceptibility testing was carried out according to the standard method by Zaidan et al. (2005) to assess the presence of antibacterial activities of the plant extracts. Plant extracts were screened for antibacterial activity against the highest five species of multi-drug resistant bacteria; E. faecium, $A$. baumanii, $P$. aeruginosa, G. morbillorum, E. cloacae, and two reference strain S. aureus ATCC 29213 and E. coli ATCC 25922. Nutrient agar mixed with bacteria at a concentration of $1 \times 10^{6} \mathrm{CFU} / \mathrm{ml}$ was poured in Petri dishes and allowed to cool. The plant extracts equivalent to $1000 \mu \mathrm{g}$, dissolved in distilled water, was applied to sterile paper discs (6 mm diameter).

To facilitate the dissolution of extracts under study, $5 \%(\mathrm{v} / \mathrm{v})$ dimethyl sulfoxide (DMSO) was added which not affected the growth of microorganisms (control experiment). The paper discs were allowed to be free from any water content by evaporation and deposited on 96well plates at room temperature, then transferred to the surface of the agar plates inoculated with the tested bacterial strains. Plates were incubated for $24 \mathrm{~h}$ at $37^{\circ} \mathrm{C}$ and antibacterial activity was evaluated by measuring the diameter of inhibition zone observed around the discs. In addition amikacin $(10 \mu \mathrm{g} / \mathrm{ml})$ was used as a positive control to determine the sensitivity of the strains by the disc diffusion method (Bauer et al., 1966). Zones of inhibition were measured in $\mathrm{mm}$ after $24 \mathrm{~h}$ of growth. The experiment was performed in triplicate. 
Determination of minimum inhibitory concentrations and minimum bactericidal concentrations

The microplate method of Eloff (1998) was used to determine the minimum inhibitory concentrations (MIC) values for plant extracts with antibacterial activity. Residues of plant extracts were dissolved in $25 \mathrm{mg} / \mathrm{ml}$ using the extracting aqueous solvent. All extracts are tested at $1000 \mu \mathrm{g} / \mathrm{ml}$ (Al-Fatimi et al., 2007) and serially diluted twofold to $15.6 \mu \mathrm{g} / \mathrm{ml}$ in a 96-multiwell polystyrene flat-bottomed microplate (Sigma-Aldrich, St. Louis, MO,USA) after which $100 \mu \mathrm{l}\left(1 \times 10^{6} \mathrm{CFU} / \mathrm{ml}\right)$ of bacteria are added to each well. The antibiotic ampicillin was added as reference antibiotic in each assay. Extract-free solution was used as the negative control. Pre-incubation absorbance values were read from an ELISA reader (Biokinetic Reader EL 350, Bio-Tek ${ }^{\mathrm{TM}}$ Instruments, Winooski, VT, USA). The microplates were then incubated overnight at $37^{\circ} \mathrm{C}$ and absorbance values were read after $24 \mathrm{~h}$ and MIC values were recorded. The experiment was performed in duplicate. Bacterial cells were transferred from the MIC plate and subcultured on solid nutrient agar by streaking on the surface of the agar. The plates were incubated overnight at $37^{\circ} \mathrm{C}$ and the minimum bactericidal concentrations (MBC) were determined after $24 \mathrm{~h}$. Plates that did not show growth were considered to be the MBC for the extract or drug used. The experiment was carried out in duplicate.

\section{Statistical analysis}

The antibacterial activity of the tested extracts comparing with standard antibiotic discs was evaluated by applying a two tailed-unpaired $t$-test. All values are expressed as the mean \pm standard deviation and $P>0.05$ values were considered to indicate statistically significant differences. Numerical data were analyzed using the Student's $t$-test using statistical Package for the Social Sciences (SPSS), SPSS Statistics versions 16.0 and later runs under Windows, Mac, and Linux.

\section{RESULTS AND DISCUSSION}

Antibacterial activity of plant extracts

In the present study ten plants belonging to seven botanical families were tested in vitro for their antibacterial activity against both five drug-resistant clinical isolates and other two standard bacterial strains. Among 10 aqueous extracts that were tested for antibacterial activity against multidrug resistant isolates, only 6 extracts $(60 \%)$ exhibited variable antibacterial activity against multidrug resistant isolates. The aqueous extracts of all the potent plants resulted in a variable zone of inhibition ranging from 8.33 to $26 \mathrm{~mm}$ for all bacteria tested (table 2).

Extracts were not strain specific and showed antibacterial activity for all seven bacterial species. Exceptions were observed for the extract of Glossostemon bruguieri, Nigella sativa, Rosmarinus officinailis, Zingiber officinale that showed no activity at all for all tested bacteria. Matricaria chmomilla and Thymus vulgaris extracts showed antibacterial activity against only $P$. aeruginosa and E. faecium with diameter of inhibition zone 14.33 and $9.66 \mathrm{~mm}$ respectively. Allium sativum extract showed no activity against both $A$. baumanii and $P$. aeruginosa, but resulted in a zone of inhibition ranged from 8.33 to $12 \mathrm{~mm}$ against other isolates. The Salvia offcinalis extract showed antibacterial activity against $A$. baumanii and E. faecium with zone of inhibition 8.66 and $11.66 \mathrm{~mm}$ respectively. Allium cepa and Foeniculum vulgare extracts were shown strong antibacterial activity with the zone of inhibition diameter ranging
Table 2: Zones of inhibition $(\mathrm{mm})$ induced by aqueous extracts from the selected plants against multi-drug resistant bacteria and the reference bacteria.

\begin{tabular}{|c|c|c|c|c|c|c|c|}
\hline \multirow[b]{3}{*}{ Plant species } & \multicolumn{7}{|c|}{ Bacterial test strains } \\
\hline & \multicolumn{5}{|c|}{ Clinical isolates } & \multicolumn{2}{|c|}{$\begin{array}{l}\text { Standard } \\
\text { strains }\end{array}$} \\
\hline & 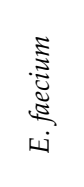 & 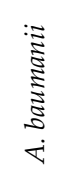 & $\begin{array}{c}0 \\
0 \\
0 \\
: 5 \\
50 \\
5 \\
5 \\
0 \\
0\end{array}$ & 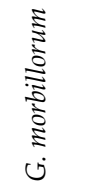 & 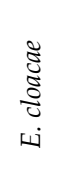 & 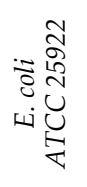 & 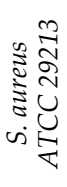 \\
\hline Allium cepa & 20 & 15.38 & 20 & 19.66 & 19 & 18.66 & 22 \\
\hline Allium sativum ${ }^{* *}$ & 10.33 & 0.0 & 0.0 & 10.66 & 12 & 10.33 & 8.33 \\
\hline $\begin{array}{l}\text { Foeniculum } \\
\text { vulgare }\end{array}$ & 17 & 19.66 & 18.33 & 20.33 & 21 & 23 & 26 \\
\hline $\begin{array}{l}\text { Glossostemon } \\
\text { bruguieri* }^{*}\end{array}$ & 0.0 & 0.0 & 0.0 & 0.0 & 0.0 & 0.0 & 0.0 \\
\hline $\begin{array}{l}\text { Matricaria } \\
\text { chmomilla }^{* *}\end{array}$ & 0.0 & 0.0 & 14.33 & 0.0 & 0.0 & 0.0 & 0.0 \\
\hline Nigella sativa* & 0.0 & 0.0 & 0.0 & 0.0 & 0.0 & 0.0 & 0.0 \\
\hline $\begin{array}{l}\text { Rosmarinus } \\
\text { officinailis* }\end{array}$ & 0.0 & 0.0 & 0.0 & 0.0 & 0.0 & 0.0 & 0.0 \\
\hline Salvia offcinalis ${ }^{* *}$ & 11.66 & 8.66 & 0.0 & 0.0 & 0.0 & 0.0 & 0.0 \\
\hline Thymus Vulgaris** & 9.66 & 0.0 & 0.0 & 0.0 & 0.0 & 0.0 & 0.0 \\
\hline Zingiber officinale* & 0.0 & 0.0 & 0.0 & 0.0 & 0.0 & 0.0 & 0.0 \\
\hline $\begin{array}{l}\text { Amikacin (10 } \\
\mu \mathrm{g} / \text { disc) }\end{array}$ & 15 & 17 & 21 & 20 & 20 & 23 & 21 \\
\hline $\begin{array}{l}\text { Negative control } \\
(\mathrm{DMSO}, 100 \mu \mathrm{l})\end{array}$ & 0.00 & 0.00 & 0.00 & 0.00 & 0.00 & 0.00 & 0.00 \\
\hline
\end{tabular}

Table 3: A summary table for the minimum inhibitory concentration (MIC) and minimum bactericidal concentrations (MBC) assays.

\begin{tabular}{|c|c|c|c|c|}
\hline No. & Microorganism & Plant species & $\begin{array}{c}\text { MICa } \\
(\mu \mathrm{g} / \mathrm{ml})\end{array}$ & $\begin{array}{c}\mathrm{MBC}^{\mathrm{b}} \\
(\mu \mathrm{g} / \mathrm{ml})\end{array}$ \\
\hline \multirow[b]{2}{*}{1} & \multirow{2}{*}{ E. faecium } & Allium cepa & 250 & 500 \\
\hline & & Foeniculum vulgare & 125 & 250 \\
\hline \multirow{2}{*}{2} & \multirow{2}{*}{ A. baumanii } & Allium cepa & 250 & 500 \\
\hline & & Foeniculum vulgare & 125 & 250 \\
\hline \multirow{2}{*}{3} & \multirow{2}{*}{ P. aeruginosa } & Allium cepa & 250 & 500 \\
\hline & & Foeniculum vulgare & 125 & 250 \\
\hline \multirow[t]{2}{*}{4} & \multirow{2}{*}{ G. morbillorum } & Allium cepa & 62.5 & 125 \\
\hline & & Foeniculum vulgare & 31.25 & 63 \\
\hline \multirow{2}{*}{5} & \multirow{2}{*}{ E. cloacae } & Allium cepa & 250 & 500 \\
\hline & & Foeniculum vulgare & 125 & 250 \\
\hline & S. aureus & Allium сера & 125 & 250 \\
\hline & ATCC 29213 & Foeniculum vulgare & 125 & 250 \\
\hline \multirow{2}{*}{7} & E. coli & Allium cepa & 125 & 250 \\
\hline & ATCC 25922 & Foeniculum vulgare & 62.5 & 125 \\
\hline
\end{tabular}

a: Minimum inhibitory concentration

b: Minimum bactericidal concentration

from 15.38 to $26 \mathrm{~mm}$ and were selected to be the most potent extracts for all test bacteria in all the assays carried out in this study (figure 1).

Activity of plant extracts under study on the multidrug resistant isolates were compared to that of standard strains and it was found that only Allium cepa, Allium sativum and Foeniculum vulgare showed antibacterial activity with the zone of inhibition diameter ranging from 8.33 to 26 against the tested strains.

Minimum inhibitory concentrations and minimum bactericidal concentrations

The two most potent extracts Allium cepa and Foeniculum vulgare showing considerable good antibacterial activity for each test organism were selected to determine MIC. 


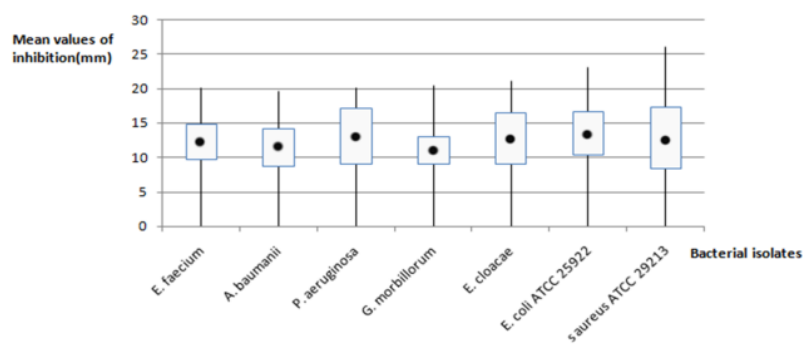

Figure 1: Mean values of inhibition $(\mathrm{mm})$ of bacteria in relation to their susceptibility to the plant extracts (means are indicated by solid circles).

Values for MICs were dependent on the bacterial species. Generally, the MIC values were low $0.031-0.250 \mathrm{mg} / \mathrm{ml}$ showing that the extracts are potent (table 3 ). However, amikacin was a more potent antibacterial than all the extracts with MIC values ranging from $0.002-0.008 \mathrm{mg} / \mathrm{ml}$. Allium cepa and Foeniculum vulgare were the most potent extracts against all the test bacteria. Foeniculum vulgare was the most potent showing the same trend of inhibition against all bacteria $0.031-0.125 \mathrm{mg} / \mathrm{ml}$ followed by Allium cepa with MIC values ranging from $0.062-0.250 \mathrm{mg} / \mathrm{ml}$.

The results of the MBC assays indicate the results of the disc diffusion assay and also the MIC determination. These results further confirmed that Allium cepa and Foeniculum vulgare were the most potent extracts. These two extracts exhibited a bactericidal nature as observed from their MBC values that ranged from $0.063-0.5 \mathrm{mg} / \mathrm{ml}$ (table 3). From the MIC and MBC assays, Gram-negative species seemed to be more resistant to plant extracts than Gram-positive species as indicated by their high MIC and MBC dvalues (table 3). Other studies carried out have also shown Gram-negative strains to be less sensitive to antibiotics than Gram-positive bacteria (Stavri et al., 2007; Doughari and Manzara, 2008). Gram-negative bacteria and mycobacteria both possess thick outer membranes that are highly hydrophobic, providing these organisms with a permeability barrier, especially towards hydrophilic compounds such as macrolide antibiotics such as erythromycin. This in part explains the observed less sensitivity to antimicrobials by Gram-negative bacteria than by Gram-positive organisms (Stavri et al., 2007). Some of the extracts used in this study have shown antibacterial activity in other studies as well.

\section{CONCLUSION}

In conclusion, in this study the extracts from Allium cepa and Foeniculum vulgare were found to have potent antibacterial activities against the clinical and reference strains. Our results support the use of these plants in traditional medicine and suggest that some of the plant extracts possess compounds with good antibacterial properties that can be used as antimicrobial agents in the search for new drugs.

\section{REFERENCES}

Adwan, G. and Mhanna, M. (2009). Synergistic effects of plant extracts and antibiotics on Staphylococcus aureus strains isolated from clinical specimens. Journal of Scientific Research, 3: 134-139.

AL-Fatimi, M., Wurster, M., Schwoder, G. and Lindequist, U. (2007) Antioxidant antimicrobial and cytotoxic activities of selected medicinal plants from Yemen. Journal of Ethnopharmacol, 111: 657-666. [DOI]

Bauer, A., Kirby, W., Sherris, J. and Turck, M. (1966). Antibiotic susceptibility testing by a standardized single disk method. American Journal of Clinical Pathology 45: 493-496.

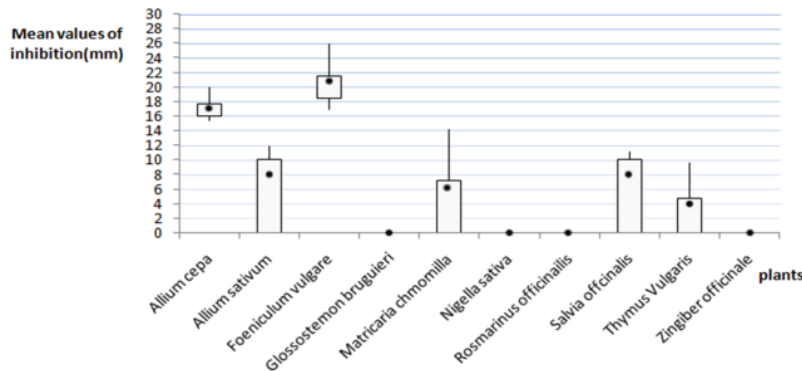

Figure 2: Mean values of antibacterial activity of plants against isolated bacteria (means are indicated by solid circles).

Betoni, Jec., Mantovani, Rp., Barbosa, Ln., Di-Stasi, Lc., Fernandes, A (2006). Synergism between plant extract and antimicrobial drugs used on Staphylococcus aureus diseases. Mem. Inst., Oswaldo Cruz. 101 No. 4. [DOI]

Bonjar, (2004). Evaluation of antibacterial properties of some medicinal plants used in Iran J. Ethnopharmacol, 94: 301-305.

Brantner, A. and Grein, E. (1994). Antibacterial activity of plant extracts used externally in traditional medicine. J. Ethnopharmacol, 44: 35-40. [DOI]

De Boer, H., Kool, A., Broberg, A., Mziray, W., Headberg, I., Levenfors, J. (2005). Antifungal and antibacterial activity of some herbal remedies from Tanzania. j. Ethophormacol, 96: 461-469. [DOI]

Doughari, J. and Manzars, S. (2008). In vitro antibacterial activity of crude leaf extract of Mangifera indica Linn. African Journal of microbiology Research, 2: 67-72.

Eloff, J. (1998). A sensitive and quick microplate method to determine the minimal inhibitory concentration of plant extracts for bacteria. Planta Medica, 64: 711-713. [DOI]

Fu, Y., Zu, Y., Chen, L., Shi, X., Wang, Z., Sun, S. and Efferth, T. (2007). Antimicrobial activity of clove and rosemary essential oils alone and in combination. Phytother Res, 21: 989-999. [DOI]

Hancock, Ew. (2005). Mechanisms of action of newer antibiotics for Grampositive pathogens. Lancet Infect Dis., 5: 209218. [DOI]

Islam, B., Khan, S., Haque, I., Alam, M., Mushfiq, M., Khan, Au. (2008) Novel Anti-adherence activity of Mulberry Leaves: inhibition of Streptococcus mutans, biofilm by 1-deoxynojirimycin isolated from Morus alba. J. Antimicrob. chemother, 62 (4): 751-757. [DOI]

Kafaru, E. (1994). Immense Help from Natives Workshop, 1st Ed, Elizabeth Kafaru, Lagos, Nigeria. Pp, 11-14.

Lee, S., Cha, K., Kim, S., Altantsetseg, S., Sarangerel, O., Nho, C. (2007) The Antimicrobial activity of essential oil from Dracocephalum foetidum against pathogenic microorganisms. J. Microbiol, 45: 53-57.

Lewis, K. and Ausubel, F. (2006). Prospects for plant-derived antibacterials Nature biotechnology, 24: 1504-7. [DOI]

Li, X., Nikaido, H. (2004). Efflux-mediated drug resistance in the bacteria. Drugs, 64: 159204. [DOI]

Murray, B. and Moellering, R. (1979). Aminoglycoside-modifying enzymes among clinical isolates of Acinetobacter calcoaceticus subsp. anitratus: explanation for high-level aminoglycoside resistance. Antimicrob Agents Chemother, 15: 190-9. [DOI]

Pfaller, M., Ronald, N., Gary. V., Kari, K. and the Sentry Participants Group. (1998). Bacterial pathogens isolated from patients with bloodstream infection: frequencies of occurrence and antimicrobial susceptibility patterns of the sentry antimicrobial surveillance program (United States and Canada). Antimicrob. Agents Chemother, 42: 17621770 .

Rangan, C. and Barceloux, D. (2009). Food additives and sensitivities. Dis. Mon., 55: 292311. [DOI]

Sharma, R., Sharma, C. and Kapoor, B. (2005). Antibacterial resistance: current problems and possible solutions, 59: 120129.

Somchit, M., Reezal, I., Nur, I. and Mutalib, A. (2003). In vitro antimicrobial activity of ethanol \& water extracts of Cassia alata. J. Ethnopharmacol, 84: 4-1. [DOI]

Stavri, M., Piddock, L. and Gibbons, S. (2007). Bacterial efflux pump Inhibitor from natural sources. Journal of antimicrobial chemotherapy, 59: 1247-1260. [DOI]

Zaidan, M., Noor, A., Badrul, A. and Aldin, A. (2005). In vitro screening of five local medicinal plants for antibacterial activity using disc diffusion method. Tropical Biomedicine, 22(2): 165-170. 